\title{
PERFORMANCE OF FINE MOTOR AND SPATIAL TASKS DURING THE MENSTRUAL CYCLE
}

\author{
Nataša ŠIMIĆ, Andrea TOKIĆ, and Marina PERIČIĆ \\ Department of Psychology, University of Zadar, Zadar, Croatia \\ Received in June 2010 \\ Accepted in October 2010
}

\begin{abstract}
Various studies have shown fluctuations in task performance during the menstrual cycle. The aim of this study was to see the effects of the menstrual cycle on performing fine motor and spatial tasks of different level of complexity in twenty students aged 18 to 21 years, with regular menstrual cycle (28 to 30 days). The students performed O'Connor Finger Dexterity Test and mental rotation test during the menstrual, late follicular, and midluteal phase. Before the tests were performed, we administered Spielberger's State-Trait Anxiety Inventory for each phase. After the tasks were completed, the subjects ranked their difficulty on Borg's scale.

The results showed the best performance in both tests in the midluteal phase (with sex hormones at their peak). The anxiety level and task difficulty ranking were the highest in the menstrual phase, when the hormone levels were the lowest.
\end{abstract}

KEY WORDS: anxiety state, oestrogen, fine motor skills, progesterone, spatial abilities

In general, men seem to have an advantage over women in spatial and mathematical skills, whereas women are more proficient in verbal skills, perceptual speed and accuracy, and fine motor skills $(1,2)$. In spatial skills, the two sexes mostly differ in tasks with three-dimensional mental rotations (3). These differences in cognitive functioning are associated with exposure of the foetal brain to different levels of sex hormones (4). According to Sherwin (4), these "organizational effects" of sex hormones permanently alter the structure and/or function of specific brain areas during foetal life, perhaps by directing the development of certain neural pathways. Significant quantities of a sex hormone seem to arrange neural substrates for a certain behaviour or function that becomes manifest after puberty, when blood levels of the same hormone are high again, which is known as the activational effect of that hormone (4).

In normally cycling women progesterone and oestrogen levels are low during the menstrual phase (cycle days 1 to 5) and high during the luteal phase (cycle days 16 to 23). In addition, oestrogen levels reach the first peak during the late follicular phase (cycle days 6 to 12) (5). Many studies have found that women better perform verbal fluency and articulation tasks during the midluteal phase or late follicular phase than in the menstrual phase (5-8). Finger dexterity has also been found significantly better in the late follicular than in the menstrual phase (9). Grooved Pegboard Test has shown superior fine motor coordination in the midluteal phase (6). In contrast, healthy young women seem to better perform spatial tasks during the menstrual phase than during the midluteal or late follicular phase $(6,10,11)$. However, other studies $(7,9)$ found no significant differences in spatial performance between menstrual cycle phases. Furthermore, Epting and Overman (12) found no relation between spatial tasks and the cycle phases, even though performance in three of the four tasks significantly differed from that of men. Higher sex 
differences were found in three dimensional than in two-dimensional spatial tasks of mental rotations, while menstrual cycle seems to affect only the first type of spatial tasks (10).

Differences between these reports may have to do with how precisely they identified cycle phase in each subject, whether they excluded anovulatory women, and how sex-sensitive were the cognitive tasks performed. Moreover, to be more exact, menstrual cycle studies should include hormone measurements. Early investigations which included measurement of hormone levels showed positive correlation between verbal fluency and oestrogen levels $(6,13)$ and negative correlation between spatial ability scores and oestrogen levels $(6,11)$ in young women. Early investigations also showed that oestrogen negatively affected performance of mental rotation task in men (14). In addition, menstrual cycle studies could make a better use of the midluteal rather than preovulatory phase because oestrogen peak in this phase is longer (10) and measurement error is less likely than in the follicular phase (15). Earlier studies did not compare performance in different cognitive tasks between the midluteal phase, when both sex hormones are high, and the late follicular phase, when only oestrogen is high $(5,9,11)$.

Several studies have shown increased anxiety and other negative emotional states during the menstrual and/or luteal phase, while positive mood was present around the ovulation time $(8,16-19)$. These shifts in mood might be related to changes in cognitive functions during the menstrual cycle.

Earlier studies did not investigate how subjects score the difficulty of a cognitive task. The exception is our study (18) showing that reaction time tasks were deemed more difficult during the premenstrual and menstrual phase. Difficulty assessment turned out to be significantly associated with menstrual pain and anxiety in the menstrual phase. This suggest that other cognitive tasks will also be assessed more difficult in the menstrual phase, due to the presence of various psychosomatic symptoms.

The aim of this study was to see how phases of the menstrual cycle affect performance in O'Connor Finger Dexterity Test and mental rotation tasks with different levels of complexity. For more precise results, we used sex-sensitive tasks during the late follicular and midluteal phase with high levels of oestrogen and progesterone and the menstrual phase with low hormone levels. We also wanted to see if performance was related to anxiety and assessment of task difficulty during the menstrual cycle.

\section{METHODS}

\section{Participants}

The study included twenty students aged 18 to 21 years with a regular menstrual cycle of 28 to 30 days who had not been using oral contraceptives. Other exclusion criteria were irregular periods, gynaecological disorders, pregnancy, history of head injury, substance abuse, and mental disorder.

Every morning the subjects took oral temperature to verify that they had normal ovulatory menstrual cycle, as demonstrated by postovulatory increase in basal body temperature (biphasic curve). All subjects were right handed and in good physical health. They had not taken medication, caffeine or alcohol within 24 hours of the experiment.

\section{O'Connor Finger Dexterity Test}

O'Connor Finger Dexterity Test is used to measure finger speed and dexterity and consists of a board with a pin tray and 100 pin holes. The subjects are asked to take the pins from the tray with their right hand and place them in the holes. The simple task involves placing one pin per hole and the complex task three pins per hole. The goal is to fill all holes in as little time as possible. Every subject was measured the total task time, expressed in seconds.

\section{Mental rotation test}

In this study we used three-dimensional objects developed by Shepard and Metzler (20) for the mental rotation test. In comparison with two-dimensional objects, three-dimensional objects better represent the spatial world and are more sensitive to sex differences and phases of the menstrual cycle (10). We asked the subjects to decide whether pairs of three-dimensional objects displayed on a computer screen were identical or mirror images of each other by pressing a corresponding key as quickly as possible. The object on the left side was presented in the upright position and the object on the right was rotated (at the angle of $0^{\circ}, 60^{\circ}, 120^{\circ}$, or $180^{\circ}$ ). The test involved three levels of complexity (easy, medium, and difficult), and each level included eight tasks. To determine task difficulty, we ran a separate test with 10 students, who did not participate in the main study. They had to score the difficulty of comparing 96 pairs of mental rotation objects using a 21-point Borg's scale, where 0 corresponded to simple and 20 to extremely difficult. The easiest tasks involved a simple object rotated 
along the $\mathrm{x}$-axis and the most difficult tasks involved complex objects rotated along the y-axis or z-axis. The average scores were 4.78 points for the easy level, 8.71 for the medium level, and 13.67 for the difficult level. Based on these scores, we selected eight tasks per level to be performed in the main study.

As more than $70 \%$ of answers in the preinvestigation phase were correct, we decided to use task completion time as the main measure of performance (in milliseconds). This measure is highly reliable (14) and indicates a strong positive correlation with the degree of angular disparity between three-dimensional objects (20). If we had also analysed accuracy, the number of tasks would have been higher due to post hoc correction for guessing (answer same/different) and due to a high percentage of correct answers. That would have considerably prolonged each of the three test sessions and resulted in lower response rate.

\section{Anxiety scoring}

To measure anxiety, we used a Croatian version of Spielberger's State-Trait Anxiety Inventory (STAI-S), whose reliability (Cronbach Alpha) is 0.93 , based on a test with 531 Croatian female students (21). Before taking either test, the students were asked to rank how well each of the 20 statements described their current state using a score range from 20 to 80 , which corresponds to the anxiety level.

\section{Procedure}

All tasks were repeated at the menstrual (day 2 of the cycle), late follicular (day 12 of the cycle), and midluteal (day 22 of the cycle) phase according to the Latin square principle. The menstrual phase is characterised by the lowest levels of oestrogen and progesterone and may involve physical discomfort and/or the use of pain relievers, which might affect performance. The late follicular phase is characterised by high oestrogen and low progesterone levels while the levels of both hormones are the highest in the midluteal phase. Each phase was determined by counting forward from the first day of the last menstrual cycle. These phases were also confirmed by counting backwards from the onset of the next menstrual phase.

One third of the subjects entered the study in the follicular phase, one in the menstrual phase, and one in the midluteal phase. Ten subjects performed the O'Connor Finger Dexterity Test first and other ten performed the mental rotation test first.
After completing the tasks, the subjects assessed their difficulty on the Borg's scale. All subjects completed the tasks with their right hand.

\section{Statistical analysis}

All data were analysed using the Statistica 7.0 software package. Analysis of variance (ANOVA) for repeated measures on one factor (phases of menstrual cycle) were used to test the significance of changes. Significant effects were analysed using Scheffe's post-hoc test.

Pearson's correlation coefficients were also calculated between performance in either task and anxiety or difficulty scores. The value of $p<0.05$ was considered statistically significant.

\section{RESULTS}

ANOVA confirmed a significant effect of cycle phase on performance in O'Connor Finger Dexterity Test (Table 1). Regardless of task complexity, the shortest completion times were recorded in the midluteal phase and the longest in the menstrual phase ( $\mathrm{p}=0.026$ for the simple task and $\mathrm{p}=0.005$ for the complex task). Scheffe's test showed significant differences in completion time between the menstrual and late follicular phase, as well as between the menstrual and midluteal phase regardless of task complexity $(\mathrm{p}<0.05)$ (Figures 1 and 2$)$.

For easy and medium difficulty mental rotation tasks, ANOVA again confirmed significant effects of the menstrual phase $(p=0.005, p=0.01$, respectively)

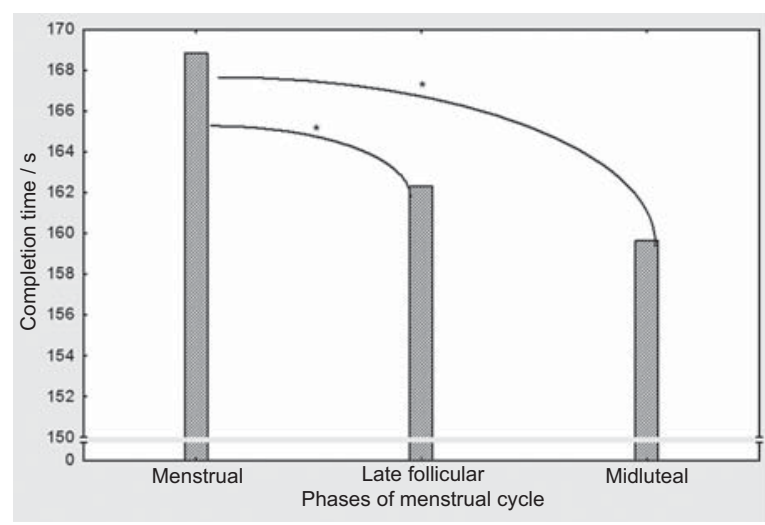

$* p<0.05$

Figure 1 Performance in O'Connor Finger Dexterity Test (simple task) through menstrual cycle phases 


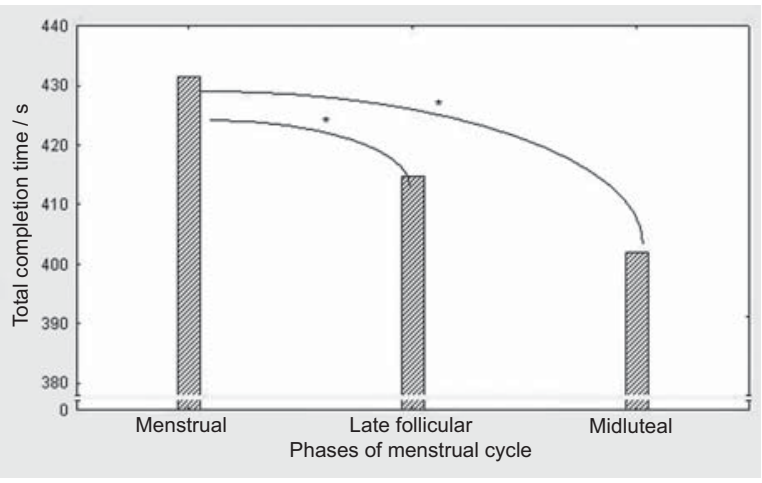

$* p<0.05$

Figure 2 Performance in O'Connor Finger Dexterity Test (difficult task) through menstrual cycle phases

(Table 1). The shortest completion times were recorded in the midluteal phase and the longest in the menstrual and late follicular phase (Figure 3). Scheffe's test showed no differences in performance between these two phases.

Anxiety changed significantly between the menstrual phase and the other two phases $(\mathrm{p}=0.05)$ (Figure 4), but not between the late follicular and midluteal phase.

Task difficulty scores followed a similar pattern. For both tests, difficulty scores were the highest in the menstrual and the lowest in the midluteal phase (Figure 5). For fine motor test, post-hoc analysis showed significant differences only between the menstrual and the midluteal phases $(\mathrm{p}=0.02)$, while for mental rotation test the differences were significant between all three phases $(\mathrm{p}=0.01)$.

We also calculated Pearson's correlation coefficients between completion time, anxiety level, and task difficulty rating based on data sets that included data from all three menstrual cycle phases. As expected, completion time correlated with task difficulty in both tests (Table 2). Anxiety, however, correlated with completion time, but not with task difficulty in O'Connor Finger Dexterity Test $(\mathrm{r}=0.02$, $\mathrm{p}>0.05$ ) and in the mental rotation test it correlated with difficulty rating $(\mathrm{r}=0.26, \mathrm{p}=0.04)$, but not with completion time (Table 2).

\section{DISCUSSION}

Our results have shown significant effects of menstrual cycle phases on finger dexterity. We however did not find differences between the midluteal phase when both oestrogen and progesterone are high and the late follicular phase, when oestrogen is high and progesterone low. This confirms earlier findings of positive correlation between oestrogen levels and fine motor performance (6) and suggests that progesterone has no such effect. Jennings et al. (13) suggest that oestrogen improves fine motor performance through the dopaminergic neurotrasmitter system and Fink et al. (23) have shown that oestrogen significantly increases D2 receptors in the striatum.

Generally speaking, mental rotation tasks are measured with completion time or accuracy. We have opted for completion time, as it is highly reliable and adequately reflects spatial skills (14). The shortest times were found in the midluteal phase, while longer times were found in the menstrual and late follicular phase. Longer completion time in the late follicular phase than in the menstrual phase echoes the results of earlier studies $(6,10)$, but in our study the difference is not significant.

With their fertility and parental-care hypothesis, Sherry and Hampson (24) suggest that high oestrogen adversely affects spatial performance, yet we have found significantly better performance in the midluteal

Table 1 Differences in performance, anxiety levels, and task difficulty ratings analysed by ANOVA

\begin{tabular}{lccc}
\hline Variable & df & F & p \\
\hline Completion time (finger dexterity test, simple task) & $2 / 38$ & 4.018 & 0.026 \\
Completion time (finger dexterity test, difficult task) & $2 / 38$ & 6.080 & 0.005 \\
Completion time (easy mental rotation task) & $2 / 38$ & 6.160 & 0.005 \\
Completion time (medium mental rotation task) & $2 / 38$ & 5.200 & 0.01 \\
Completion time (difficult mental rotation task) & $2 / 38$ & 1.200 & 0.312 \\
Anxiety levels & $2 / 38$ & 8.70 & 0.001 \\
Task difficulty rating (finger dexterity test) & $2 / 38$ & 3.05 & 0.05 \\
Task difficulty rating (mental rotation test) & $2 / 38$ & 19.36 & 0.001 \\
\hline
\end{tabular}




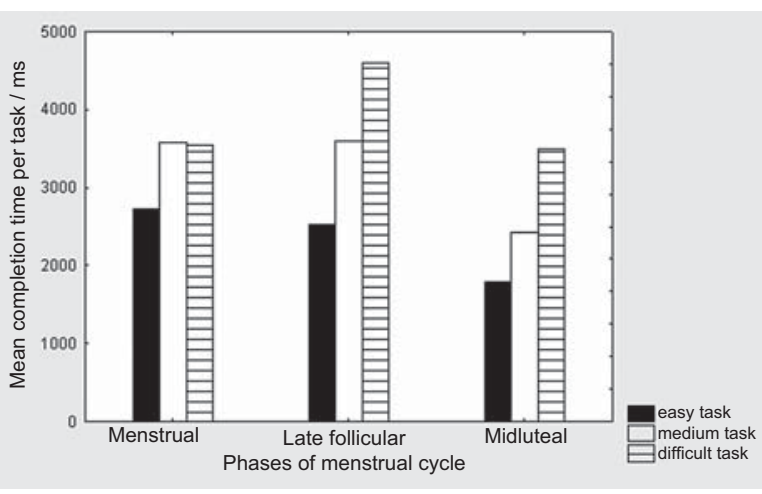

Figure 3 Performance in mental rotation Test through menstrual cycle phases

phase than in the late follicular phase, even though oestrogen levels are similar between these phases. This may suggest that better spatial performance is more related to high progesterone levels or a complex interaction between both sex hormones than to oestrogen alone. This is indirectly supported by two studies $(25,26)$ which suggest that high levels of progesterone reduce lateralisation, which in turn improves spatial performance through the use of verbal strategies in solving mental rotation tasks in women (27). Hausmann and Güntürkün (25) propose that progesterone reduces cortico-cortical transmission by suppressing the excitatory responses of neurons to glutamate as well as by enhancing their inhibitory responses to GABA. This combined effect can result in a reduction of functional asymmetry and in the best performance in the midluteal phase.

As expected, hormone deficit during the menstrual phase adversely affected performance in mental rotation tasks. It may have additionally been affected by menstrual pain and/or anxiety in the menstrual phase.

To our knowledge, our study is the first to include different levels of complexity for mental rotation tasks. We found no significant differences in performance

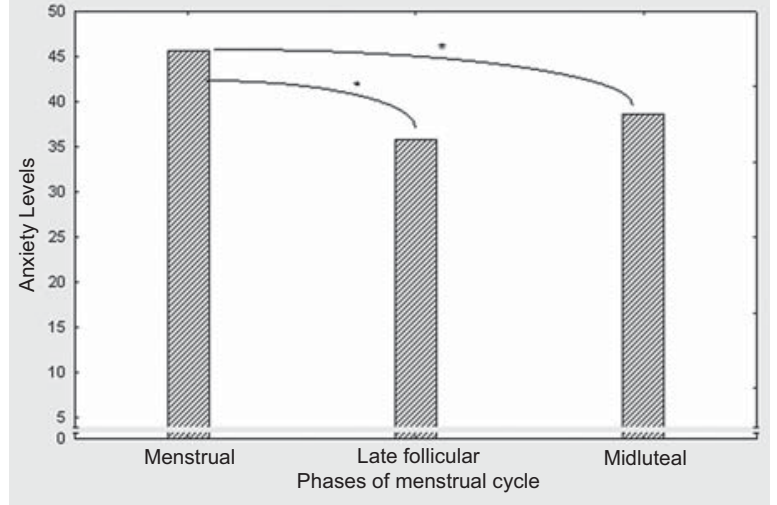

$* p<0.05$

Figure 4 Anxiety levels through menstrual cycle phases

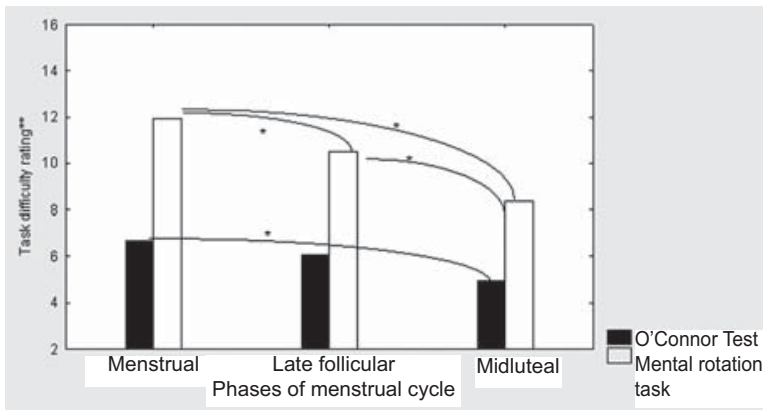

$* p<0.05$

**Borg's scale

Figure 5 Task difficulty rating through menstrual cycle phases

between the cycle phases for the most difficult set of mental rotation tasks. This suggest that performance of complex tasks might be affected by other variables in addition to sex hormones. According to Roberts and Bell (28) one of these variables is familiarisation with the computer on which mental rotation tasks are performed. It is also possible that our subjects used different strategies to solve complex tasks. For example, Peters et al. (29) found that $37.8 \%$ of the female students used a hand or fingers to better

Table 2 Correlations between task completion times, anxiety, and task difficulty ratings

\begin{tabular}{lccccc}
\hline & \multicolumn{2}{c}{$\begin{array}{c}\text { Finger dexterity test } \\
\text { Time / }\end{array}$} & \multicolumn{3}{c}{$\begin{array}{c}\text { Mental rotation test } \\
\text { Time / ms }\end{array}$} \\
\hline & Simple task & Difficult task & Easy task & Medium task & Difficult task \\
\hline Anxiety level & $0.36^{* *}$ & $0.33^{* *}$ & 0.10 & 0.07 & 0.02 \\
Difficulty rating & $0.32^{*}$ & $0.36^{* *}$ & $0.36^{* *}$ & $0.30^{*}$ & 0.10 \\
\hline
\end{tabular}

${ }^{*} p<0.05 ; r=0.254$

$* * p<0.01 ; r=0.330$ 
visualise and solve more difficult tasks with rotation along the top/bottom axis and left/right axis. They also found a significant correlation between the frequency of playing with Lego blocks in childhood and performance in more difficult mental rotation tasks.

In our study, anxiety levels and difficulty ratings showed a similar pattern. In the midluteal phase they were the lowest. This could partly explain improved performance in O'Connor Finger Dexterity Test, but not in the mental rotation test, as we found no significant correlation between these two and performance in the midluteal phase. Our anxiety pattern corresponds to earlier investigations (17-19), which have shown the highest anxiety in the menstrual phase and low anxiety in the late follicular and midluteal phases. Sherwin (30) explains mood changes during the menstrual cycle through the agonistic effect of oestrogen on serotonin. At high levels, it is expected to induce a positive mood. Furthermore, Smith et al. (31) report progesterone's anti-anxiety effect, but we found no inverse correlation between anxiety and progesterone in our study, as anxiety states did not differ between the late follicular (high oestrogen/low progesterone) and midluteal (high oestrogen and progesterone) phases.

\section{CONCLUSION}

Our study is somewhat limited by the small sample restricted to a female university student population. In addition, our assumptions on hormone levels are based on basal body temperature and not on actual measurements. In addition, we have not included a matching male population to act as control and perhaps show sex differences in task performance.

However, this study has its merits too. It confirms earlier findings on the effect menstrual cycle phases (that is, oestrogen and progesterone levels) on fine motor and spatial performance, but it also shows for the first time that other variables become more involved as mental rotation tasks become more complex. We hope that future studies will address this issue further.

\section{REFERENCES}

1. Kimura D. Sex, sexual orientation and sex hormones influence human cognitive function. Curr Opin Neurobiol 1996;6:259-63.
2. Maylor EA, Reimers S, Choi J, Collaer ML, Peters M, Silverman I. Gender and sexual orientation differences in cognition across adulthood: age is kinder to women than to men regardless of sexual orientation. Arch Sex Behav 2007;36:235-49.

3. Silverman I, Choi J, Peters M. The Hunter-Gatherer theory of sex differences in spatial abilities: Data from 40 countries. Arch Sex Behav 2007;36:261-8.

4. Sherwin BB. Estrogen and cognitive functioning in women. Endocr Rev 2003;24:133-51.

5. Hampson E, Kimura D. Reciprocal effects of hormonal fluctuations on human motor and perceptual-spatial skills. Behav Neurosci 1988;102:456-59.

6. Maki PM, Rich JB, Rosenbaum RS. Implicit memory varies across the menstrual cycle: estrogen effects in young women. Neuropsychologia 2002;40:518-29.

7. Rosenberg L, Park S. Verbal and spatial functions across the menstrual cycle in healthy young women. Psychoneuroendocrinology 2002;27:835-41.

8. Symonds CS, Gallagher P, Thompson JM, Young AH. Effects of the menstrual cycle on mood, neurocognitive and neuroendocrine function in healthy premenopausal women. Psychol Med 2004;34:93-102.

9. Hromatko I. Utjecaj estrogena na shvaćanje prostornih odnosa, perceptivnu brzinu i fine motoričke sposobnosti [Influence of estrogen on spatial abilities, perceptual speed and fine motor skills, in Croatian]. Suvremena psihologija 2001;4:61-71.

10. Phillips K, Silverman I. Differences in the relationship of menstrual cycle phase to spatial performance on two- and three-dimensional tasks. Horm Behav 1997;32:167-75.

11. Hausmann M, Slabbekoorn D, Van Goozen SHM, CohenKettenis PT, Güntürkün O. Sex hormones affect spatial abilities during the menstrual cycle. Behav Neurosci 2000;114:1245-50.

12. Epting LK, Overman WH. Sex-sensitive tasks in men and women. A search for performance fluctuations across the menstrual cycle. Behav Neurosci 1998;112:1304-17.

13. Jennings PJ, Janowsky JS, Orwoll E. Estrogen and sequential movement. Behav Neurosci 1998;112:154-9.

14. Kozaki T, Yasukouchi A. Relationships between salivary estradiol and components of mental rotation in young men. J Physiol Antropol 2008;27:19-24.

15. Fehring RJ, Schneider M, Raviele K. Variability in the phases of the menstrual cycle. J Obstet Gynecol Neonatal Nurs 2005;35:376-84.

16. Henderson J, Whissell C. Changes in women's emotions as a function of emotion valence self-determined category of premenstrual distress, and day in the menstrual cycle. Psychol Rep 1997;80:1272-4

17. Proroković A, GregovLj. Changes in somepsychophysiological variables during menstrual cycle. Medica Jadertina 1997;1:517.

18. Šimić N, Manenica I. Promjene nekih psihofizioloških varijabli tijekom menstrualnog ciklusa [Changes in some psychophisiological variables during the menstrual cycle, in Croatian]. Radovi Filozofskog fakulteta u Zadru 1998;36:7990.

19. Šimić N. Neuroticizam i psihofiziološke promjene tijekom menstrualnog ciklusa [Neuroticism and psychopysiological changes during the menstrual cycle, in Croatian]. Medica Jadertina 1999;29:5-20. 
20. Shepard RN, Metzler J. Mental rotation of three dimensional objects. Science 1971;71:701-3.

21. Spielberger CD. [State-Trait Anxiety Inventory, in Croatian]. Jastrebarsko: Naklada Slap; 2000.

22. Borg G. A note on a category scale with "ratio properties" for estimating perceived exertion. Reports from the Institute of Applied Psychology the University of Stockholm. 1973;36:16.

23. Fink G, Summer BEH, Rosie R, Grace O, Quin JP. Estrogen control of central neurotransmission: effects of mood, mental state and memory. Cell Mol Neurobiol 1996;16:325-44.

24. Sherry DF, Hampson E. Evolution and the hormonal control of sexually-dimorphic spatial abilities in humans. Trends Cogn Sci 1997;1:50-5.

25. Hausmann M, Güntürkün O. Steroid fluctuations modify functional cerebral asymmetries: the hypothesis of progesterone-mediated interhemispheric decoupling. Neuropsychologia 2000;38:1362-74.
26. Hausmann M, Tegenthoff M, Sanger J, Janssen F, Güntürkün O, Schwenkreis P. Transcallosal inhibition across the menstrual cycle: a TMS study. Clin Neurophysiol 2006;117:26-32.

27. Halpern DF. Sex differences in cognitive abilities. $3^{\text {rd }}$ ed. Mahwah, New Jersey: Lawrence Erlbaum Associates; 2000.

28. Roberts JE, Bell MA. Sex differences on a computerized mental rotation task disappear with computer familiarization. Percept Mot Skills 2000;91:1027-34.

29. Peters M, Laeng B, Latham K, Jackson M, Zaiyouna R, Richardson C. A redrawn Vandenberg and Kuse mental rotations test: different versions and factors that affect performance. Brain Cogn 1995;28:39-58.

30. Sherwin BB. Estrogen and mood in women. Endocrinologist 2005;3:180-5.

31. Smith MJ, Keel BA, Greenberg BD, Adams BA, Schmidt PJ, Rubinow DA, Wassermann EM. Menstrual cycle effects on cortical excitability. Neurology 1999;53:2069-72. 


\section{Sažetak \\ UČINKOVITOST U ZADACIMA FINE MOTORIKE I PROSTORNIH ODNOSA TIJEKOM MENSTRUALNOG CIKLUSA}

Različita su istraživanja pokazala promjene učinkovitosti tijekom menstrualnog ciklusa. U zadacima u kojima su uspješnije žene, najveća učinkovitost događa se tijekom kasne folikularne ili srednje lutealne faze. U zadacima u kojima su pak uspješniji muškarci najveća je učinkovitost nađena u menstrualnoj fazi.

Na osnovi uporabe zadataka fine motorike i prostornih zadataka različith razina kompleksnosti, cilj ovog istraživanja bio je ispitati utjecaj menstrualnog ciklusa na kognitivne funkcije.

$\mathrm{U}$ istraživanju je sudjelovalo dvadeset ispitanica, dobi od 18 do 21 godinu, s redovitim menstrualnim ciklusima (28 do 30 dana). Ispitanice su izvodile O'Connorov deksterimetar i zadatke mentalne rotacije tijekom menstrualne, kasne folikularne i srednje lutealne faze. Prije izvođenja zadataka, u svakoj fazi ciklusa primijenjen je Spielbergerov upitnik stanja anksioznosti. Nakon izvođenja zadataka, ispitanice su procjenjivale njihovu težinu na Borgovoj skali.

Rezultati su pokazali najbolju učinkovitost u oba zadatka u fazi visokih razina spolnih hormona (srednja lutealna faza). Stanje anksioznosti i procijenjene težine zadataka bili su najviši u menstrualnoj fazi, kada su razine spolnih hormona najniže.

KLJUČNE RIJEČI: estrogen, fine motoričke vještine, progesteron, prostorne sposobnosti, stanje anksioznosti

\section{CORRESPONDING AUTHOR:}

Nataša Šimić, Ph.D.

Department of Psychology, University of Zadar

Krešimirova obala 2, 23000 Zadar, Croatia

E-mail:nsimic@unizd.hr 